\title{
Recent advances in understanding and managing
}

\section{malabsorption: focus on microvillus inclusion disease [version}

\section{1; peer review: 4 approved]}

\author{
Dulari Jayawardena1', Waddah A. Alrefai ${ }^{1,2}$, Pradeep K. Dudeja ${ }^{1,2}$, Ravinder K. Gill1
}

${ }^{1}$ Division of Gastroenterology \& Hepatology, University of Illinois at Chicago, Chicago, IL, USA

2Jesse Brown VA Medical Center, Chicago, IL, USA

V1 First published: 05 Dec 2019, 8(F1000 Faculty Rev):2061

https://doi.org/10.12688/f1000research.20762.1

Latest published: 05 Dec 2019, 8(F1000 Faculty Rev):2061

https://doi.org/10.12688/f1000research.20762.1

\section{Abstract}

Microvillus inclusion disease (MVID) is a rare congenital severe malabsorptive and secretory diarrheal disease characterized by blunted or absent microvilli with accumulation of secretory granules and inclusion bodies in enterocytes. The typical clinical presentation of the disease is severe chronic diarrhea that rapidly leads to dehydration and metabolic acidosis. Despite significant advances in our understanding of the causative factors, to date, no curative therapy for MVID and associated diarrhea exists. Prognosis mainly relies on life-long total parenteral nutrition (TPN) and eventual small bowel and/or liver transplantation. Both TPN and intestinal transplantation are challenging and present with many side effects. A breakthrough in the understanding of MVID emanated from seminal findings revealing mutations in MYO5B as a cause for MVID. During the last decade, many studies have thus utilized cell lines and animal models with knockdown of MYO5B to closely recapitulate the human disease and investigate potential therapeutic options in disease management. We will review the most recent advances made in the research pertaining to MVID. We will also highlight the tools and models developed that can be utilized for basic and applied research to increase our understanding of MVID and develop novel and effective targeted therapies.

Keywords

MVID, malabsorption, epithelial transport, diarrhea, trafficking

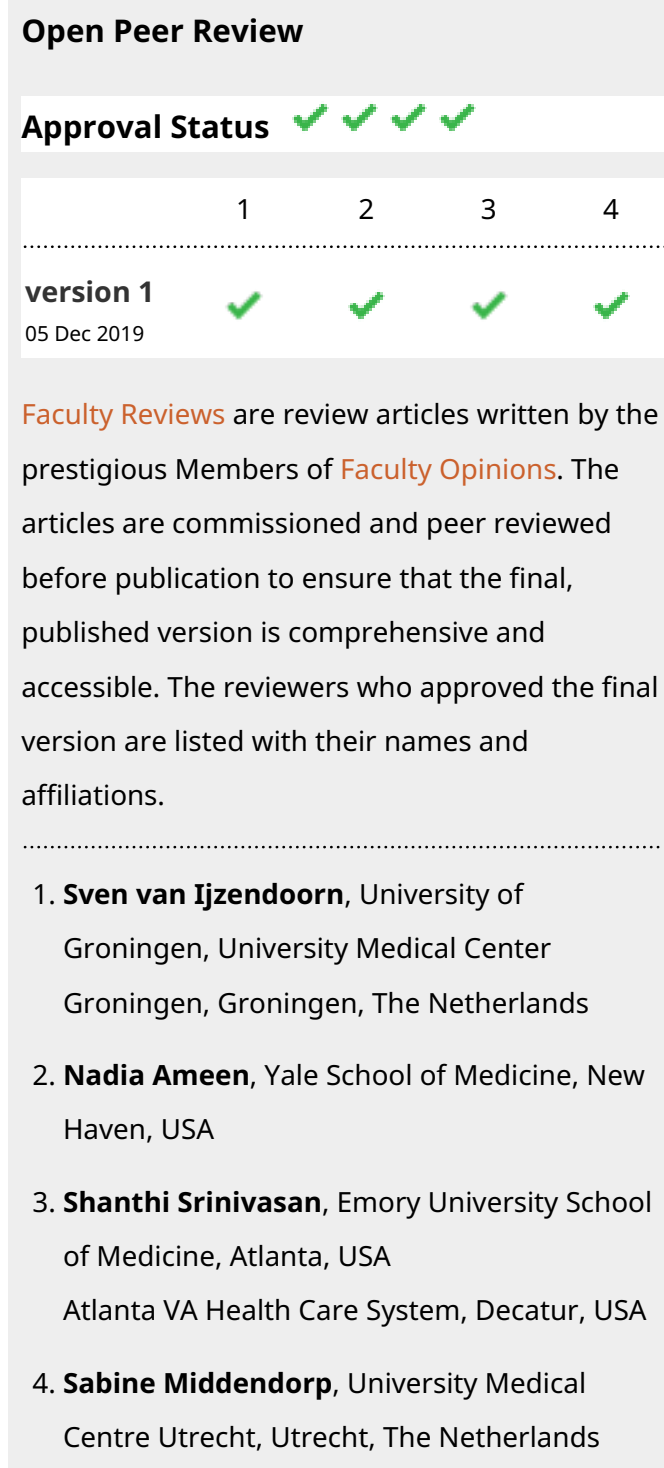

Faculty Reviews are review articles written by the prestigious Members of Faculty Opinions. The articles are commissioned and peer reviewed before publication to ensure that the final, published version is comprehensive and accessible. The reviewers who approved the final version are listed with their names and affiliations.

\section{Sven van Ijzendoorn, University of Groningen, University Medical Center Groningen, Groningen, The Netherlands \\ 2. Nadia Ameen, Yale School of Medicine, New Haven, USA \\ 3. Shanthi Srinivasan, Emory University School of Medicine, Atlanta, USA Atlanta VA Health Care System, Decatur, USA \\ 4. Sabine Middendorp, University Medical Centre Utrecht, Utrecht, The Netherlands} Any comments on the article can be found at the 
end of the article.

Corresponding author: Ravinder K. Gill (RGILL@uic.edu)

Author roles: Jayawardena D: Writing - Original Draft Preparation, Writing - Review \& Editing; Alrefai WA: Writing - Original Draft Preparation, Writing - Review \& Editing; Dudeja PK: Writing - Review \& Editing; Gill RK: Writing - Original Draft Preparation, Writing Review \& Editing

Competing interests: No competing interests were disclosed.

Grant information: The author(s) declared that no grants were involved in supporting this work.

Copyright: ( 2019 Jayawardena D et al. This is an open access article distributed under the terms of the Creative Commons Attribution License, which permits unrestricted use, distribution, and reproduction in any medium, provided the original work is properly cited.

How to cite this article: Jayawardena D, Alrefai WA, Dudeja PK and Gill RK. Recent advances in understanding and managing malabsorption: focus on microvillus inclusion disease [version 1; peer review: 4 approved] F1000Research 2019, 8(F1000 Faculty Rev):2061 https://doi.org/10.12688/f1000research.20762.1

First published: 05 Dec 2019, 8(F1000 Faculty Rev):2061 https://doi.org/10.12688/f1000research.20762.1 


\section{Diagnosis of microvillus inclusion disease}

In 1978, Davidson et al. presented a case report of five infants with persistent severe diarrhea from birth and marked abnormalities of absorption associated with failure to thrive, leading to death in four infants ${ }^{1}$. The common histological abnormalities in duodenal mucosa from those infants were villus atrophy, crypt hypoplasia (without an increase in mitoses or inflammatory cell infiltrate in the lamina propria) and absence of a brush border in villus enterocytes, and an increase in lysosome-like inclusions ${ }^{2,3}$. Originally referred to as Davidson's disease, congenital microvillus atrophy, and intestinal microvillus dystrophy, the disease was named microvillus inclusion disease (MVID) in 1989 by Cutz et al. ${ }^{4}$.

As with all rare genetic diseases, the diagnosis of MVID was quite challenging until recently and required histological evaluation for confirmation. It is important to note that MVID has a very low incidence, making it extremely difficult to investigate its pathophysiology ${ }^{5}$. The morphological anomalies observed in the enterocytes of patients with MVID are widely utilized in disease diagnosis ${ }^{2}$. Until recently, the gold standard in diagnosing MVID was combined light and electron microscopy of small bowel biopsy samples of patients. The abnormalities are mainly observed in the small intestine and less frequently in the colon ${ }^{6}$. However, some studies have shown that the colon and rectum biopsies may also contain characteristic features which would be useful in diagnosing MVID ${ }^{2,6,7}$.

The key hallmarks which aid in the differential diagnosis include blunted or absent microvilli, accumulation of secretory granules, and microvillus inclusions (MIs) in the epithelial cells $^{2,8}$. As depicted in Figure 1, these granules, in most cases, are positive for periodic acid Schiff (PAS) stain and CD10 with an intracellular PAS or CD10 positive line in enterocytes that is commonly detected. Another apical marker which may aid in the identification of the trademark MIs is villin, an apical surface marker of enterocytes ${ }^{9}$. An important factor which should be accounted for during histological evaluation of

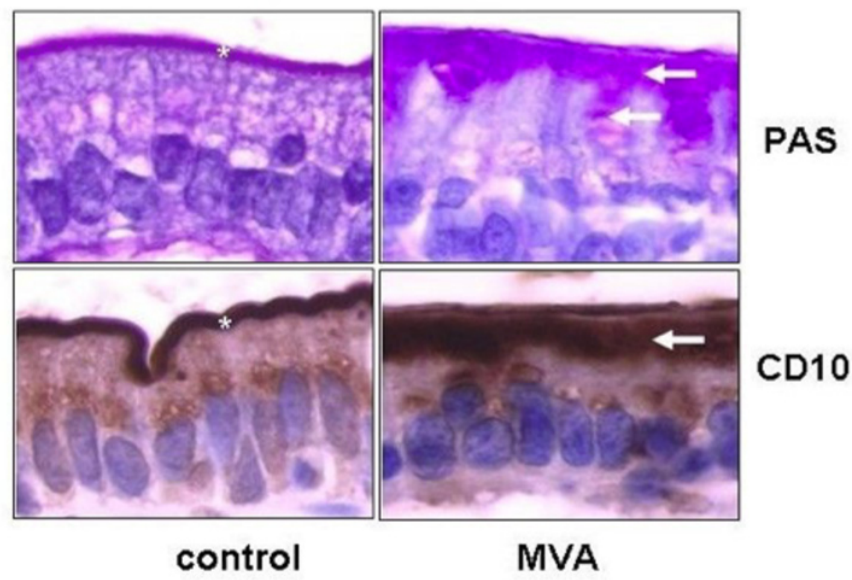

Figure 1. Characteristic histological features of microvillus inclusion disease reprinted with permission from Ruemmele et al. ${ }^{2}$. MVA, microvillous atrophy; PAS, periodic acid Schiff

biopsies is sampling variability and patient-to-patient variability. The diagnosis is confirmed further by genetic testing, which can specifically identify the genetic anomaly of each patient. In this instance, currently, there is a registry which tracks each genetic variation observed in MVID patients to facilitate ease of access to patient-related data for clinicians involved in the management of this rare genetic disorder ${ }^{10}$.

\section{Differential diagnosis}

There are several features that differentiate MVID from other diarrheal conditions with similar clinical presentation including the onset at birth, absence of inflammation, presence of vacuoles containing granules with the characteristic PAS and CD10 positive stain observed under light microscopy, and presence of MIs (Table 1). Other congenital disorders such as chloride and sodium diarrhea can be easily excluded from biochemical assays or genetic testing ${ }^{6,11}$. Tufting enteropathy is a disorder with similar onset and blunted villi; however, the presence of surface apical tufts as opposed to apical inclusion bodies in

Table 1. Characteristic features of congenital diarrheal disorders.

\begin{tabular}{|c|c|c|}
\hline Congenital disease & Major gene/s mutated & Distinctive feature(s) \\
\hline Microvillus inclusion disease & MYO5B $^{12}, S_{T X 3^{13}}, S T X B P 2^{14}$ & $\begin{array}{l}\text { Blunted microvilli, microvillus } \\
\text { inclusions }\end{array}$ \\
\hline Chloride diarrhea & SLC26A3 or Down Regulated in Adenoma $(D R A)^{15}$ & $\begin{array}{l}\text { High-chloride diarrhea (fecal } \mathrm{Cl}^{-} \\
>90 \mathrm{mM} / \mathrm{L} \text { ) and normal microvilli }\end{array}$ \\
\hline Sodium diarrhea & $\begin{array}{l}\text { SPLINT2 (serine peptidase inhibitor 2), GUCY2C } \\
\text { (guanylate cyclase C), and SLC9A3 (sodium } \\
\text { hydrogen exchanger } 3 \text { (NHE3) }\end{array}$ & $\begin{array}{l}\text { High-sodium diarrhea (fecal } \mathrm{Na}^{+} \\
>145 \mathrm{mM} / \mathrm{L} \text { ) and normal microvilli }\end{array}$ \\
\hline Tufting enteropathy & EPCAM (epithelial cell adhesion molecule) ${ }^{17}$ & $\begin{array}{l}\text { Presence of surface apical tufts with } \\
\text { blunted villi }\end{array}$ \\
\hline $\begin{array}{l}\text { Enteroendocrine cell } \\
\text { dysgenesis }\end{array}$ & NEUROG3 (neurogenin-3) $)^{18}$ & $\begin{array}{l}\text { Lack of enteroendocrine cells with } \\
\text { normal villi }\end{array}$ \\
\hline Abetalipoproteinemia & MTTP (microsomal triglyceride transfer protein) ${ }^{19}$ & $\begin{array}{l}\text { Fat vacuoles with foamy cytoplasm } \\
\text { and normal villi }\end{array}$ \\
\hline
\end{tabular}


enterocytes distinguishes tufting enteropathy from MVID. Enteroendocrine cell dysgenesis can be differentiated from MVID by the lack of enteroendocrine cells and the presence of normal microvilli. Finally, abetalipoproteinemia is distinguished from MVID by the presence of fat vacuoles and a foamy cytoplasm ${ }^{20}$.

\section{Clinical manifestations of microvillus inclusion disease}

Earlier studies in patients with MVID showed high stool volume ( 150 to $300 \mathrm{~mL} / \mathrm{kg} / \mathrm{day}$ ) with remarkably elevated sodium content (approximately $100 \mathrm{mmol} / \mathrm{L})^{2,21}$. The diarrhea present in MVID is considered to be non-osmotic in nature (i.e. fecal ion gap $<100 \mathrm{mOsm}$ ) and is persistent even when the patient is unfed $^{22}$. This type of diarrhea is categorized as electrolyte transport-related diarrhea caused by mechanisms involving net secretion of anions (chloride, bicarbonate, or potassium) and/or net inhibition of sodium or chloride absorption ${ }^{11,23-25}$. Steatorrhea and impaired glucose absorption have also been reported in MVID patients ${ }^{26,27}$. Various studies have shown mislocalization of apical membrane-targeted proteins such as sucrase isomaltase, alkaline phosphatase, and sodium hydrogen exchanger 3 (NHE3) in MVID, which might partly explain the pathophysiology of malabsorption and diarrhea ${ }^{28}$. Due to the high-volume and persistent diarrhea observed in these patients, the main life-saving treatment option remains life-long total parenteral nutrition (TPN). The use of life-long TPN poses many complications including sepsis and worsening cholestatic liver disease that may require intestinal transplantation. However, outcomes of intestinal transplantation remain poor $^{2,27}$. Owing to the immature nature of the enterocytes present in infants with MVID, absorption of essential nutrients is hampered and, therefore, recent studies are directed at developing therapeutic agents which are capable of increasing the maturity of the enterocytes to ultimately recuperate the loss of absorptive capacity of the small intestine ${ }^{29}$. Although little progress has been made in developing treatment options, the growing research has certainly highlighted relevant mechanisms linking perturbation in cellular trafficking and signaling pathways to functional physiological defects leading to malabsorption and chronic diarrhea ${ }^{30}$.

\section{Pathophysiology of microvillus inclusion disease}

\section{Studies in patients and human cell lines}

The identification of gene mutations linked to trafficking pathways in MVID has paved the way for further research into better understanding of this intricate and challenging enteropathy. The major mutation observed in MVID patients is in the $M Y O 5 B$ gene, the key molecular motor gene regulating trafficking of important proteins into the brush border of the intestinal epithelial cells ${ }^{31}$. An online registry for MVID patients and their mutations has been generated which currently has 188 MVID patients ${ }^{10}$. Although the majority of MVID patients exhibit mutations in $M Y O 5 B$, mutations in other genes have also been identified that present with less severe enteropathy. For example, mutations in soluble N-ethylmaleimide-sensitive factor attachment protein receptor (SNARE) protein syntaxin-3 (STX3) cause a variant form of MVID with lateral microvilli and occasional microvillus occlusions ${ }^{13}$. In addition, patients with mutations in $S T X B P 2$, encoding the syntaxin-binding protein-2 (MUNC18-2) protein, also have intestine-related hallmarks of MVID besides their primary diagnosis of familial hemophagocytic lymphohistiocytosis type 5 (FHL5), a hyper-inflammatory immune disorder ${ }^{14}$. Recent studies by Dhekne et al. ${ }^{32}$ provided further evidence that $M Y O 5 B, S T X 3$, and STXBP2 genes are functionally linked in MVID patients. In this regard, analysis of subcellular distribution of STX3 and MUNC18-2 in enterocytes of intestinal biopsies from patients with $M Y O 5 B$ or STXBP2 mutations showed that MUNC18-2 and STX3 accumulated in intracellular puncta in the enterocytes of MVID patients as compared to apical localization in brush border plasma membrane in control enterocytes. In addition to the native biopsy samples, in vitro Caco2 model epithelium has been used extensively to recapitulate the loss of MYO5B on epithelial polarity and intracellular trafficking. Interestingly, $M Y O 5 B$ knockdown mimicked the loss of apical microvilli and lack of polarity and was associated with internalization of several apical membrane transporters such as $\mathrm{Na}^{+} / \mathrm{H}^{+}$exchanger NHE3 $3^{31,33,34}$ and Down Regulated in Adenoma (DRA) ${ }^{34}$. While both NHE3 and DRA localization were significantly reduced on the apical membrane of human MVID enterocytes and $M Y O 5 B$ knockdown (MYO5B-KD) C2BBe cells, the localization of cystic fibrosis transmembrane conductance regulator (CFTR) was mostly preserved ${ }^{28}$. Functional studies confirmed that Forskolin-stimulated CFTR ion transport was intact in MYO5B-KD T84 cells ${ }^{28}$.

Another recent study using stable $M Y O 5 B-\mathrm{KD}$ in CaCo2-BBE cells established the critical role of MYO5B interactions with specific RAB small GTPases (RAB8A and RAB11) in MVID $^{35}$. MYO5B-KD cells showed loss of microvilli; however, no MIs were observed. The expression of WT MYO5B in $M Y O 5 B-K D$ cells restored microvilli, while the expression of MYO5B-P660L, an MVID-associated mutation found within the Navajo population (that cannot bind to RAB11A), induced the formation of MIs but did not rescue the MYO5B-KD phenotype. On the contrary, the expression of a RAB8A binding-deficient MYO5B mutant partly restored the microvilli loss, but no inclusions were formed. These studies demonstrated that the disruption of the MYO5B-RAB11A interaction results in the formation of MIs, whereas MYO5B-RAB8A binding is important for microvilli formation ${ }^{35}$. Recent studies by Vogel et al. identified Rab11- and/or Rab8-positive recycling endomembrane compartments that were enriched with apical membrane proteins, including STX3 and NHE3, in MVID patients' enterocytes ${ }^{36}$.

With respect to mechanisms underlying the origin of inclusions and microvillus loss, a recent review by Schneeberger et al. ${ }^{29}$ highlighted three potential models or a combination of these models to explain the pathological hallmarks of MVID. In the first, described as a trafficking model, defects in vesicle trafficking caused by $M Y O 5 B$ or STX3 mutations result in the subapical accumulation of vesicles and in the lack of appropriately polarized apical proteins. In the second model (recycling model), perturbations in the recycling and delivery of apical 
recycling endosomes (AREs) result in the subapical accumulation of apical proteins and in the formation of microvilli-containing macropinosomes. As discussed above, MYO5B is required for the localization of RAB11A-positive AREs, which contain various signaling molecules, such as pyruvate dehydrogenase kinase (PDK1), protein kinase $\mathrm{C}(\mathrm{PKCi})$, and serine threonine protein kinase (MST4) colocalized with ezrin ${ }^{28,32,37}$. The third local induction model proposes that in MVID, RAB11A-positive AREs accumulate and function as a subapical signaling platform to induce ectopic intracellular microvillus formation ${ }^{37}$. The presence of MIs in MVID is the pathognomonic finding based on microscopy of intestinal tissues in diagnosing patients. However, the formation of these inclusions in enterocytes is not yet defined as a cause or consequence of the disease, although the latter is more accepted in the current clinical setting. Plausibly, MIs may represent a secondary effect of overall disrupted epithelial polarity in MVID ${ }^{38}$.

\section{Animal models to study microvillus inclusion disease}

In the first report of animal models of MVID initiated about 4 years ago, in 2015, Schneeberger et al. and Cartón-Garcia et al. described the deletion of the $M Y O 5 B$ gene in mice and its close phenotypic similarity to the human disease ${ }^{39,40}$. The inducible intestine-specific knockdown of $M Y O 5 B$ could successfully recapitulate human MVID in just 4 days post induction. However, germline knockdown of $M Y O 5 B$ in mice very closely showcases hallmarks of MVID in the duodenum during the gestational stage (day 20 of gestation) and in newborn mice ${ }^{40}$. In addition, in a recently developed swine model published as an abstract form, where the mutated gene in $M Y O 5 B(P 663 L)$ is introduced, the disease phenotype is similarly discernable ${ }^{41}$. The pig model is the first large animal model of human MVID that develops diarrhea shortly after birth and may be useful for preclinical studies.

Similar to studies in cell lines and patients with MVID, intestinal tissues from MYO5B-knockout mice showed decreased localization of apical protein NHE3 but not $\mathrm{CFTR}^{42}$. Also, the tamoxifen-inducible VilCre ${ }^{\mathrm{ERT} 2}$;MYO5B ${ }^{\text {flox/flox }}$ model demonstrated a loss of apical NHE3, sodium glucose transporter-1 (SGLT1), DRA, and aquaporin-7 (AQP7) ${ }^{38}$. These mice did not show an intestinal barrier defect, based on Ussing chamber analysis, but exhibited decreased SGLT1 activity and increased CFTR activity. However, in MVID patient intestinal explants, increased permeability has been reported ${ }^{43}$. Also, mislocalization of CFTR was demonstrated in some patient biopsies ${ }^{34}$. These differences further highlight that knockout of myo5B may not necessarily resemble the presence of a mutated MYO5B protein. In addition, it is unclear if these models have defects in the large intestine, as most of the studies have utilized the small intestine alone.

\section{Enteroids derived from models of microvillus inclusion disease}

Intestinal enteroids have recently emerged as an important model which closely recapitulates the human disease phenotype due to epithelial defects. Because of the presence of all types of epithelial cells and the self-renewing capacity of the enteroids, these cultured native intestinal epithelial cells represent a superior model as compared to cancer cell lines. In this regard, there is a significant scarcity of patient-derived enteroids from MVID ${ }^{13}$. This is mainly due to the lack of a reasonably large patient cohort and the very early onset and fatality of the disease. However, intestinal enteroids generated from different mouse models where $M Y O 5 B$ is knocked down exhibited abnormalities with features similar to those seen in the small intestinal tissues of MVID patients ${ }^{33,38,42}$. A recent study conducted by Mosa et al. underscored the importance of studying the pathology of MVID by demonstrating the ability to rescue the defects present in MUNC18-2 (mutated in FHL5) knockdown mouse enteroids by expressing the human WT protein and not by the mutant FHL5 patient variant (P477L) ${ }^{36,44}$. It is noteworthy to mention that owing to the rare nature of the enteropathy, long-term preservation of patient samples to generate organoids is warranted to enhance the current understanding of the disease.

\section{Caenorhabditis elegans nematode model}

Although very simple, consisting of only a few enterocytes, the $C$. elegans nematode model possesses a close resemblance to human intestinal epithelium with distinct polarization of apical and basolateral membranes with a prominent microvillus brush border. In this regard, by silencing various components in the V-ATPase complex (an important regulator of cellular trafficking), the authors identified that specific subunits of the protein complex, in particular V0, are upstream of other genetic defects which leads to a MVID-like phenotype in this model $^{45}$. Due to the simplicity of the model, this may be important for use as a platform to study the development of the disease as well as potential cellular mechanisms, which can be a target for developing drug molecules for MVID management.

\section{Extraintestinal manifestations in microvillus inclusion disease}

The $M Y O 5 B$ gene is expressed in all epithelial tissues, but the most prominent phenotype is observed in the intestine. However, several extraintestinal pathologies have also been reported in other tissues. In this regard, pathologies identified include renal Fanconi syndrome, cholestasis, hematuria, and pneumonia ${ }^{27,46}$. Therefore, animal models of MVID could be useful to study these conditions that may be missed in humans owing to the complications associated with disease diagnosis, the very early onset, and lack of survival. With respect to biliary dysfunction, a recent study found cholestasis in $30 \%$ of their patient cohort, which was characterized by a low level of serum gamma-glutamyl transpeptidase $(\mathrm{GGT})^{47}$. The study reported abnormalities in the recycling of MYO5B and RAB11A and mistargeting of bile salt export pump (BSEP) to the canalicular membrane of hepatocytes. Although cholestasis in MVID patients was previously thought to be solely due to TPN-related toxicity, evidence has emerged supporting cholestasis in the absence of TPN due to apical trafficking defects in MVID hepatocytes ${ }^{48}$. In this regard, the investigators noted that the unexpected low levels of GGT in MVID patients contrasted with the high levels of this surrogate in cases of liver failure associated with TPN. In a very recent preliminary study conducted in $M Y O 5 B$ 
null mice and pigs with Navajo mutation (published in an abstract form), the authors demonstrated an interference with apical membrane trafficking in hepatocytes. Specifically, multidrug resistance associated protein-2 (MRP2) and BSEP were mislocalized to subapical compartments. In addition, dipeptidyl peptidase-4 (DPPIV) enzyme was mistrafficked and the liver bile canaliculi lacked branching, highlighting the importance of $M Y O 5 B$ in studying liver dysfunction associated with MVID patients $^{49}$.

\section{Conclusions}

Malabsorptive disorders lead to retarded growth and nutritional deficiencies. The complex nature of these disorders poses a challenge for treatment options ${ }^{50}$. Understanding the pathophysiological mechanisms of malabsorption should improve current management protocols and immensely enhance our knowledge regarding intestinal physiology. In this regard, increased understanding of the intriguing malabsorptive disorders of childhood such as MVID should offer new insights at the cellular and molecular levels to unravel the link between cellular trafficking and epithelial absorptive processes. The research in the field of MVID has considerably progressed over the last decade. The generation of novel mouse models with $M Y O 5 B$ deletion has been successful in recapitulating various hallmark features of MVID. So far, the utilization of these models has not only substantiated the role of $M Y O 5 B$ and trafficking machinery in the disease's pathogenesis but also underscored the importance of cellular trafficking mechanisms in maintaining optimal function of nutrient and electrolyte transporters such as SGLT1 and NHE3. Unlike the in vitro and in vivo mouse models, where loss of $M Y O 5 B$ ideally disrupts intracellular trafficking in all cells, the manifestation of abnormalities in MVID patients is patchy and sometimes confined to a few enterocytes ${ }^{5}$. In addition, although some studies described the presence of abnormalities in the colon and rectum of MVID patients, most animal models focused only on the duodenum and upper small intestine $^{35,38,39,42}$. More studies in the distal parts of the small intestine and colon should broaden our understanding of the compensatory mechanisms that the intestine may employ to adapt in consequences of $M Y O 5 B$ mutations. The mechanisms underlying lipid malabsorption associated with MVID remain elusive. Therefore, investigations to explore the molecular basis for dysregulation of lipid absorption in MVID patients and mouse models are warranted. The inducible MYO5B-deficient mouse models have the additional advantage of studying the consequences of time- and age-dependent occurrences of disease-specific hallmarks ${ }^{29,33,38}$. Although MVID is a rare disorder, the organoids derived from MVID patients can provide unique opportunities to model the disease and modify the mutated genes by state-of-the-art approaches, including the CRISPR/Cas9 gene editing system, for rescuing the defective phenotype ${ }^{29}$.
1. Davidson GP, Cutz E, Hamilton JR, et al.: Familial enteropathy: a syndrome of protracted diarrhea from birth, failure to thrive, and hypoplastic villus atrophy. Gastroenterology. 1978; 75(5): 783-90. PubMed Abstract | Publisher Full Text

2. Ruemmele FM, Schmitz J, Goulet O: Microvillous inclusion disease (microvillous atrophy). Orphanet J Rare Dis. 2006; 1: 22 PubMed Abstract | Publisher Full Text | Free Full Text

3. F Vogel GF, Hess MW, Pfaller K, et al:: Towards understanding microvillus inclusion disease. Mol Cell Pediatr. 2016; 3(1): 3 .

PubMed Abstract | Publisher Full Text | Free Full Text | F1000 Recommendation

4. Cutz E, Rhoads JM, Drumm B, et al:: Microvillus inclusion disease: an inherited defect of brush-border assembly and differentiation. N Engl J Med. 1989; 320(10): 646-51. PubMed Abstract | Publisher Full Text

5. F Canani RB, Castaldo G, Bacchetta R, et al.: Congenital diarrhoeal disorders: advances in this evolving web of inherited enteropathies. Nat Rev Gastroenterol Hepatol. 2015; 12(5): 293-302.

PubMed Abstract | Publisher Full Text | F1000 Recommendation

6. Al-Daraji WI, Zelger B, Zelger B, et al.: Microvillous inclusion disease: a clinicopathologic study of 17 cases from the UK. Ultrastruct Pathol. 2010; 34(6): 327-32.

PubMed Abstract | Publisher Full Text

7. Schofield DE, Agostini RM Jr, Yunis EJ: Gastrointestinal microvillus inclusion disease. Am J Clin Pathol. 1992; 98(1): 119-24.

PubMed Abstract | Publisher Full Text

8. Groisman GM, Amar M, Livne E: CD10: a valuable tool for the light microscopic diagnosis of microvillous inclusion disease (familial microvillous atrophy). Am J Surg Pathol. 2002; 26(7): 902-7.

PubMed Abstract | Publisher Full Text

9. Sherman PM, Mitchell DJ, Cutz E: Neonatal enteropathies: defining the causes of protracted diarrhea of infancy. J Pediatr Gastroenterol Nutr. 2004; 38(1): $16-26$.

PubMed Abstract | Publisher Full Text

10. van der Velde KJ, Dhekne HS, Swertz MA, et al:: An overview and online registry of microvillus inclusion disease patients and their MYO5B mutations. Hum
Mutat. 2013; 34(12): 1597-605.

PubMed Abstract | Publisher Full Text

11. Terrin G, Tomaiuolo R, Passariello A, et al:: Congenital diarrheal disorders: an updated diagnostic approach. Int J Mol Sci. 2012; 13(4): 4168-85. PubMed Abstract | Publisher Full Text | Free Full Text

12. F Müller T, Hess MW, Schiefermeier N, et al:: MYO5B mutations cause microvillus inclusion disease and disrupt epithelial cell polarity. Nat Genet. 2008; 40(10): 1163-5.

PubMed Abstract | Publisher Full Text | F1000 Recommendation

13. Wiegerinck $\mathrm{CL}$, Janecke AR, Schneeberger $\mathrm{K}$, et al:: Loss of syntaxin 3 causes variant microvillus inclusion disease. Gastroenterology. 2014; 147(1): 65-68.e10. PubMed Abstract | Publisher Full Text

14. Stepensky P, Bartram J, Barth TF, et al.: Persistent defective membrane trafficking in epithelial cells of patients with familial hemophagocytic lymphohistiocytosis type 5 due to STXBP2/MUNC18-2 mutations. Pediatr Blood Cancer. 2013; 60(7): 1215-22.

PubMed Abstract | Publisher Full Text

15. Mäkelä S, Kere J, Holmberg C, et al.: SLC26A3 mutations in congenital chloride diarrhea. Hum Mutat. 2002; 20(6): 425-38. PubMed Abstract | Publisher Full Text

16. Janecke AR, Heinz-Erian P, Müller T: Congenital Sodium Diarrhea: A Form of Intractable Diarrhea, With a Link to Inflammatory Bowel Disease. J Pediatr Gastroenterol Nutr. 2016; 63(2): 170-6. PubMed Abstract | Publisher Full Text

17. F Sivagnanam M, Mueller $\mathrm{JL}$, Lee $\mathrm{H}$, et al.: Identification of EpCAM as the gene for congenital tufting enteropathy. Gastroenterology. 2008; 135(2): 429-37. PubMed Abstract | Publisher Full Text | Free Full Text | F1000 Recommendation

18. Wang J, Cortina G, Wu SV, et al:: Mutant Neurogenin-3 in Congenital Malabsorptive Diarrhea. N Engl J Med. 2006; 355(3): 270-80. PubMed Abstract | Publisher Full Text

19. Gregg RE, Wetterau JR: The molecular basis of abetalipoproteinemia. Curr Opin Lipidol. 1994; 5(2): 81-6. PubMed Abstract | Publisher Full Text

20. Weinstein MA, Pearson KD, Agus SG: Abetalipoproteinemia. Radiology. 1973 
108(2): 269-73.

PubMed Abstract | Publisher Full Text

21. Oktavia Sari $Y$, Bahari MB, Ibrahim B: Clinical review of total parenteral nutrition use among pediatric: Critics and outcomes. International Journal of Pharmacy \& Life Sciences. 2013; 4(4).

Reference Source

22. Canani RB, Terrin G: Recent progress in congenital diarrheal disorders. Curr Gastroenterol Rep. 2011; 13(3): 257-64 PubMed Abstract | Publisher Full Text

23. F Thiagarajah JR, Kamin DS, Acra S, et al:: Advances in Evaluation of Chronic Diarrhea in Infants. Gastroenterology. 2018; 154(8): 2045-2059.e6. PubMed Abstract | Publisher Full Text | Free Full Text | F1000 Recommendation

24. Nathavitharana KA, Green NJ, Raafat F, et al:: Siblings with microvillous inclusion disease. Arch Dis Child. 1994; 71(1): 71-3. PubMed Abstract | Publisher Full Text | Free Full Text

25. Schiller LR: Diarrhea. Med Clin North Am. 2000; 84(5): 1259-74. PubMed Abstract | Publisher Full Text

26. lancu TC, Manov I: Ultrastructural aspects of enterocyte defects in infancy and childhood. Ultrastruct Pathol. 2010; 34(3): 117-25. PubMed Abstract | Publisher Full Text

27. Siahanidou T, Koutsounaki E, Skiathitou AV, et al:: Extraintestinal manifestation in an infant with microvillus inclusion disease: complications or features of the disease? Eur J Pediatr. 2013; 172(9): 1271-5. PubMed Abstract | Publisher Full Text

28. Kravtsov DV, Ahsan MK, Kumari V, et al: Identification of intestinal ion transport defects in microvillus inclusion disease. Am J Physiol Gastrointest Liver Physiol. 2016; 311(1): G142-55.

PubMed Abstract | Publisher Full Text | Free Full Text

29. F Schneeberger K, Roth S, Nieuwenhuis EES, et al:: Intestinal epithelial cell polarity defects in disease: lessons from microvillus inclusion disease. Dis Model Mech. 2018; 11(2): pii: dmm031088 PubMed Abstract | Publisher Full Text | Free Full Text | F1000 Recommendation

30. Kravtsov D, Mashukova A, Forteza R, et al.: Myosin $5 b$ loss of function leads to defects in polarized signaling: implication for microvillus inclusion disease pathogenesis and treatment. Am J Physiol Gastrointest Liver Physiol. 2014; 307(10): G992-G1001.

PubMed Abstract | Publisher Full Text | Free Full Text

31. Ruemmele FM, Müller T, Schiefermeier N, et al:: Loss-of-function of MYO5B is the main cause of microvillus inclusion disease: 15 novel mutations and a CaCo-2 RNAi cell model. Hum Mutat. 2010; 31(5): 544-51. PubMed Abstract | Publisher Full Text

32. F Dhekne HS, Pylypenko O, Overeem AW, et al:: MYO5B, STX3, and STXBP2 mutations reveal a common disease mechanism that unifies a subset of congenital diarrheal disorders: A mutation update. Hum Mutat. 2018; 39(3): 333-44.

PubMed Abstract | Publisher Full Text | Free Full Text | F1000 Recommendation

33. Thoeni CE, Vogel GF, Tancevski I, et al:: Microvillus inclusion disease: loss of Myosin vb disrupts intracellular traffic and cell polarity. Traffic. 2014; 15(1): 22-42.

PubMed Abstract | Publisher Full Text

34. Ameen NA, Salas PJ: Microvillus inclusion disease: a genetic defect affecting apical membrane protein traffic in intestinal epithelium. Traffic. 2000; 1(1): 76-83.

PubMed Abstract | Publisher Full Text

35. Knowles BC, Roland JT, Krishnan M, et al:: Myosin Vb uncoupling from RAB8A and RAB11A elicits microvillus inclusion disease. J Clin Invest. 2014; 124(7): 2947-62.

PubMed Abstract | Publisher Full Text | Free Full Text

36. F Vogel GF, Janecke AR, Krainer IM, et al: Abnormal Rab11-Rab8-vesicles cluster in enterocytes of patients with microvillus inclusion disease. Traffic. 2017; 18(7): 453-64.

PubMed Abstract | Publisher Full Text | Free Full Text | F1000 Recommendation

37. Dhekne HS, Hsiao NH, Roelofs $P$, et al:: Myosin Vb and Rab11a regulate phosphorylation of ezrin in enterocytes. J Cell Sci. 2014; 127(Pt 5): 1007-17. PubMed Abstract | Publisher Full Text

38. F Weis VG, Knowles BC, Choi E, et al:: Loss of MYO5B in mice recapitulates Microvillus Inclusion Disease and reveals an apical trafficking pathway distinct to neonatal duodenum. Cell Mol Gastroenterol Hepatol. 2016; 2(2): 131-57.

PubMed Abstract | Publisher Full Text | Free Full Text | F1000 Recommendation

39. Schneeberger K, Vogel GF, Teunissen $\mathrm{H}$, et al:: An inducible mouse model for microvillus inclusion disease reveals a role for myosin $\mathrm{Vb}$ in apical and basolateral trafficking. Proc Natl Acad Sci U S A. 2015; 112(40): 12408-13. PubMed Abstract | Publisher Full Text | Free Full Text

40. F Cartón-García F, Overeem AW, Nieto R, et al.: Myo5b knockout mice as a model of microvillus inclusion disease. Sci Rep. 2015; 5: 12312. PubMed Abstract | Publisher Full Text | Free Full Text | F1000 Recommendation

41. Engevik AC, Coutts A, Saqui-Salces M, et al.: Gene Editing of Swine Myosin Vb Induces Microvillus Inclusion Disease and Loss of Apical Sodium Transporters with Maintenance of CFTR in Enterocytes. FASEB J. 2019; 33(1_supplement): 869.14 .

Reference Source

42. F Engevik AC, Kaji I, Engevik MA, et al.: Loss of MYO5B Leads to Reductions in $\mathrm{Na}^{+}$Absorption With Maintenance of CFTR-Dependent $\mathrm{Cl}$ Secretion in Enterocytes. Gastroenterology. 2018; 155(6): 1883-1897.e10. PubMed Abstract | Publisher Full Text | Free Full Text | F1000 Recommendation

43. Bijlsma PB, van der Wal A, Scholten G, et al.: Increased paracellular macromolecular transport and subnormal glucose uptake in duodenal biopsies of patients with microvillus inclusion disease. J Pediatr Gastroentero Nutr. 1999; 28(5): 547. Publisher Full Text

44. F Mosa MH, Nicolle O, Maschalidi S, et al:: Dynamic Formation of Microvillus Inclusions During Enterocyte Differentiation in Munc18-2-Deficient Intestinal Organoids. Cell Mol Gastroenterol Hepatol. 2018; 6(4): 477-493.e1. PubMed Abstract | Publisher Full Text | Free Full Text | F1000 Recommendation

45. Bidaud-Meynard A, Nicolle O, Heck M, et al.: The loss of V0-ATPase induces Microvillus inclusion-like disease in C. elegans. bioRxiv. 2018; 412122. Publisher Full Text

46. Golachowska MR, van Dael CM, Keuning $\mathrm{H}$, et al: $M$ YYO5B mutations in patients with microvillus inclusion disease presenting with transient renal Fanconi syndrome. J Pediatr Gastroenterol Nutr. 2012; 54(4): 491-8. PubMed Abstract | Publisher Full Text

47. F Gonzales E, Taylor SA, Davit-Spraul A, et al:: MYO5B mutations cause cholestasis with normal serum gamma-glutamyl transferase activity in children without microvillous inclusion disease. Hepatology. 2017; 65(1): 164-73. PubMed Abstract | Publisher Full Text | F1000 Recommendation

48. F Girard M, Lacaille F, Verkarre V, et al:: MYO5B and bile salt export pump contribute to cholestatic liver disorder in microvillous inclusion disease. Hepatology. 2014; 60(1): 301-10.

PubMed Abstract | Publisher Full Text | F1000 Recommendation

49. Engevik AC, Coutts A, LeBlanc C, et al:: 240-Role of Myosin Vb in Trafficking of Apical Membrane Proteins in Hepatocytes. Gastroenterology. 2019; 156(6): S-1184.

Publisher Full Text

50. Keller J, Layer P: The Pathophysiology of Malabsorption. Viszeralmedizin. 2014; 30(3): 150-4.

PubMed Abstract | Publisher Full Text | Free Full Text 


\section{Open Peer Review}

\section{Current Peer Review Status:}

\section{Editorial Note on the Review Process}

Faculty Reviews are review articles written by the prestigious Members of Faculty Opinions. The articles are commissioned and peer reviewed before publication to ensure that the final, published version is comprehensive and accessible. The reviewers who approved the final version are listed with their names and affiliations.

\section{The reviewers who approved this article are:}

\section{Version 1}

\section{Sabine Middendorp}

Department of Paediatric Gastroenterology, Wilhelmina Children's Hospital, University Medical Centre Utrecht, Utrecht, The Netherlands

Competing Interests: No competing interests were disclosed.

\section{Shanthi Srinivasan}

${ }^{1}$ Department of Medicine, Division of Digestive Diseases, Emory University School of Medicine, Atlanta, GA, USA

2 Research-Gastroenterology, Atlanta VA Health Care System, Decatur, GA, USA

Competing Interests: No competing interests were disclosed.

\section{Nadia Ameen}

Department of Pediatrics/Gastroenterology and Hepatology, Yale School of Medicine, New Haven, CT, USA

Competing Interests: No competing interests were disclosed.

\section{Sven van Ijzendoorn}

Department of Biomedical Sciences of Cells and Systems, University of Groningen, University Medical Center Groningen, Groningen, The Netherlands

Competing Interests: No competing interests were disclosed. 
The benefits of publishing with F1000Research:

- Your article is published within days, with no editorial bias

- You can publish traditional articles, null/negative results, case reports, data notes and more

- The peer review process is transparent and collaborative

- Your article is indexed in PubMed after passing peer review

- Dedicated customer support at every stage

For pre-submission enquiries, contact research@f1000.com 